\title{
Analytical Study of Eccentric Beam Column Joint
}

\author{
Dattatreya S. Nikam ${ }^{1}$, V. S. Shingade ${ }^{2}$ \\ ${ }^{1}$ P. G. Student, Civil Department, Trinity College of Engineering and Research, Pune, India \\ ${ }^{2}$ Assistant Professor, Civil Department, Trinity College of Engineering \& Research, Pune, India
}

\begin{abstract}
The beam-column joints are critical regions inreinforced concrete frames subjected to severe seismic attack. Beam moment reversal can produce high shear force and bond breakdown in the joint resulting in cracking of the joint. Bond strength is influenced by several factors such as bar diameter, clear cover of concrete over the bar, grade of the concrete, transverse reinforcement. Usually most of the beam column joints in reinforced concrete building are concentric but, for architectural reasons the beam column connections in reinforced concrete building is eccentric. In eccentric beam-column connections the axis of the spandrel beams is offset from the axis of the column. Bending in the spandrel beams produces internal compression and tension forces that act on the joint at an eccentric with the column centroid, thus producing torsion in the joint. The torsion in the joint will produce additional shear stresses, and it is unclear to what extent this will affect the shear capacity of the joint. To achieve the ductile detailing at beam column in reinforced concrete structures are given in IS 13920-1993 and also in ACI-318-14. The transverse reinforcement in the joint helps to confine the concrete and also increase the strength of the beam-column joint. When the shear forces at the joints become large, diagonally cracking occurs in the joint and then the crushing of concrete will take place in the beam-column joints. In the present study reinforced concrete building of G+10 stories having 4 bays in both the axis is analyzed using ETABS. The finite element model of external beam-column joint is developed and analyzed using ANSYS 11.0. Comparison is made between Indian code (IS 13920-1993) and American code (ACI 318-14) for reinforcement provision for exterior beam column joint. Analysis is done in terms of deflection, maximum stress, minimum stress and von misses stress. According to Indian code (IS 13920-1993) the development length recommended is more than required. The code revised for several times hence, the provision for the development length remains unchanged. The minimum column width recommended according to IS code is $300 \mathrm{~mm}$ which is true as per the study. The confinement length according to Indian code is more than the required.
\end{abstract}

Keywords: critical region, bond strength, transverse reinforcement, Column centroid, SNSYS 11.0, maximum stress, minimum stress etc

\section{Introduction}

\subsection{General}

The behavior of reinforced concrete moment resisting frame structures in recent earthquakes in all over the world has highlighted the consequences of poor performances of beam column joints. Beam column connections are critical regions in reinforced concrete frame and it is designed to endure the severe earthquakes.

According to the design capacity philosophy, the hinges must form on beam only. Since from last three decades, extensive research has been carried out to study the performance of the beam column joint under seismic forces through analytical and experimental studies. It is commonly accepted that, it is uneconomical to design reinforced concrete structures for severe ground motion without damage.

Earthquakes are one of the most feared natural phenomena that are relatively unexpected and whose impact is sudden due to the almost instantaneous destruction that a major earthquake can produce. Severity of ground shaking at a given location during an earthquake can be minor, moderate and strong which relatively occur frequently, occasionally and rarely respectively. Hence, the main intention is to make building earthquake-resistant that resist the effect of ground shaking although it may get damaged severely but would not collapse during even the strong earthquake. Thus, the safety of people and contents is assured in earthquake-resistant buildings. This is a major objective of seismic design codes throughout the world. When a RC beam column joints is subjected to earthquake loading, the beams compression (C) and tension(T) from bending are directly transmitted to the joint at the beam-column interfaces, which produces relatively large joint shear forces. In eccentric beam column connections, due to eccentricity the transmitted forces in the joint can introduce torsion in the joint and joint shear stress increases due to eccentric in the beam column joint.

\subsection{Beam- Column joints (B-C joint)}

The functional requirement of a joint, which is the zone of intersection of beams and column, is to enable the adjoining members to develop and sustain their ultimate capacity. The demand on this finite size element is always severe especially under seismic loading. The joints should have adequate strength and stiffness to resist the internal forces induced by the framing members. The joint is defined as the portion of the column within the depth of the deepest beam that frames into the column. In a moment resisting frame, three types of joints can be identified as interior joint, exterior joint and corner joint (Fig.1). When four beams frame into the vertical faces of a column, the joint is called as an interior joint. When one beam frames into a vertical face of the column and two other beams frame from perpendicular directions into the joint, then the joint is called as an exterior joint. When a beam each frames into two adjacent vertical faces of a column, then the joint is called as a corner joint.

The severity of forces and demands on the performance of these joints calls for greater understanding of their seismic behavior. These forces develop complex mechanisms involving bond and shear within the joint 


\section{International Journal of Science and Research (IJSR) \\ ISSN (Online): 2319-7064}

Index Copernicus Value (2016): 79.57 | Impact Factor (2015): 6.391

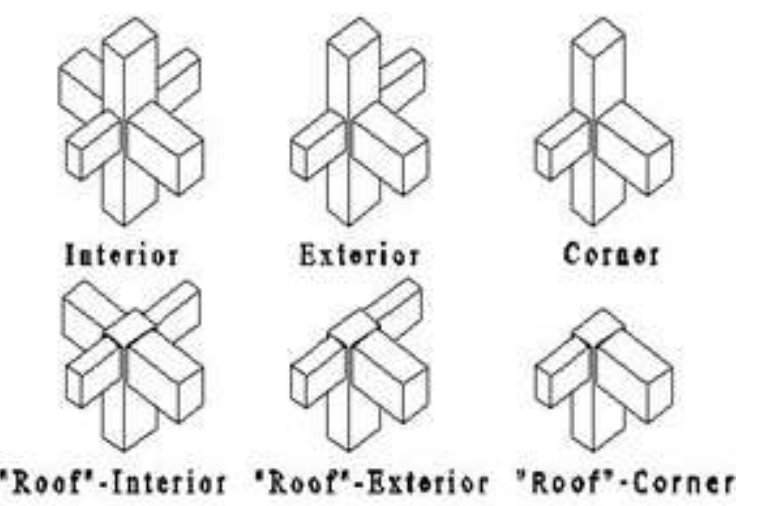

Figure 1.1: Types of joints in frame

A typical exterior beam column joint representing the development length according, member size and confinement reinforcement of column is shown in Figure 1.2

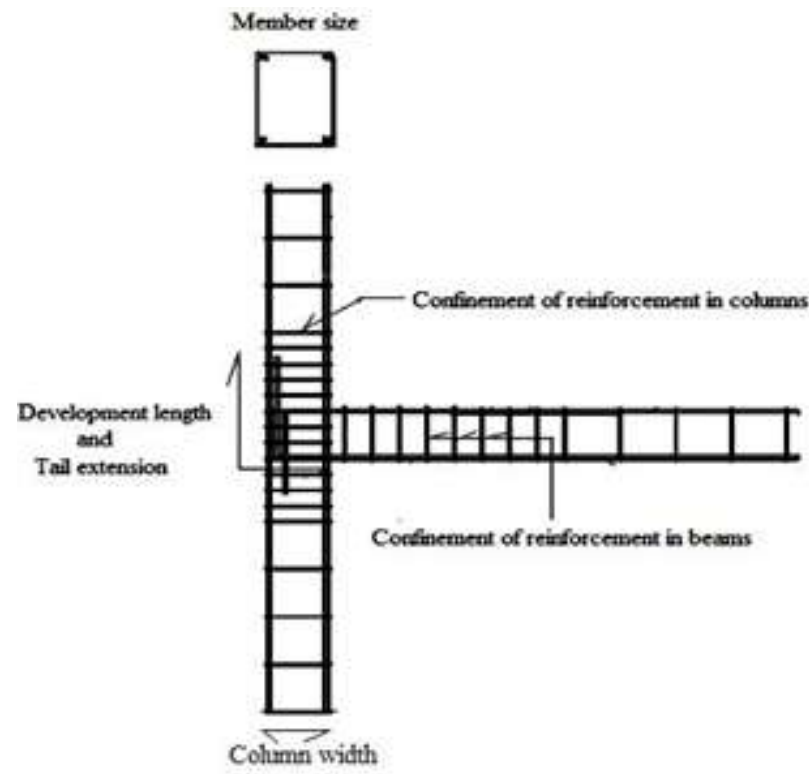

Figure 1.2.1: Reinforcement details for a typical beam column joint

\subsection{Objective of the Project}

To study the influence of development length of reinforcement in beam-column joint with Indian code (IS: 13920-1993) and American code (ACI 318M-14).

\section{Literature Review}

\subsection{General}

The review of some literatures related to eccentric beam column joint has been carried out. Literature review is mainly concentrated on the behavior of beam-column joint with eccentricity and without eccentricity of various parameters like stress, deflection, shear deformation.

\section{Joh, Goto, and Shibata}

Carried out five cruciform beam-column connections it includes two eccentric connections. The displacement ductility of two specimens having eccentricity was only between $2.5 \mathrm{~mm}$ and $5 \mathrm{~mm}$, while specimens without eccentricity had displacement ductility ranging from $4 \mathrm{~mm}$ to $8 \mathrm{~mm}$. In the specimens having a flush face of the column and eccentric beams, the flush side of the joint had 4 to 5 times larger joint shear deformations compare to offset side of the joints.

\section{Gregory S. Raffaelle and James K. Wight}

Carried out four cruciform eccentric beam-column connections and observed inclined (torsional) cracks in the beam-column joint and strain in the joint hoop reinforcement on the flush side were larger than compare to the offset side, and which leads to additional shear stress from torsion. The author suggested that shear strength of the eccentric beamcolumn connections were overestimated with the current joint. ACI-ASCE Committee 352 design recommendations and by this it could be rectified using a proposed equation for reduced effective joint width.

\section{Cheng-Cheng Chen and Gwang-Kai Chen}

Explained the guidelines of eccentric corner beam column joints with connecting spread-ended beams given satisfactory performance in developing strength, stiffness, ductility, and energy dissipation capacity, of beam-column joint. Six corner beam-column joints were designed as per ACI 318-95. All the six specimens were designed in three type of configuration. JC specimen consist a concentric joints, JE contained an eccentricity of $100 \mathrm{~mm}$, and JS series contained an eccentricity of $100 \mathrm{~mm}$ with spread ended beam. The ratio of beam moment to column moment strength was 2.1 for JE and JC specimen and for JS specimen moment strength ratio were 2.0. The eccentricity caused more severe crack damage. On the exterior (flush) side of the joint than on the interior side and greater hoop strains in the exterior leg than in the interior leg. The strength ratio of all the specimens was greater than one. Nevertheless, the strength ratio of JS series was higher than JE by 6 to $9 \%$ and higher than JC by 2 to $5 \%$.

\section{Shyh-Jiann Hwang and Hung-Jen Lee}

Studied that the analytical model derived from the strut-andtie mechanism and it satisfies the force equilibrium, strain compatibility and the constitutive laws of cracked reinforced concrete. It is noted that the crushing strength of concrete in a strut and tie mechanism it is referred to as an effective compression strength. By this strut and tie mechanism it also satisfies the equilibrium compatibility and it also satisfies the stress and strain characteristics of cracked reinforced concrete. The average strength ratio is 1.05 and coefficient of variation is $22 \%$.

\section{Susanto Teng and Hua Zhou}

Demonstrated six interior beam-column joint and examples assigned as S1 to S6 were initially outlined, built, and tested under cyclic loading examples $\mathrm{S} 1, \mathrm{~S} 2$, and $\mathrm{S} 3$ considered as arrangement 1 and while arrangement 2 comprise of S4, S5, S6 examples eccentricity provides for $\mathrm{S} 1$ and $\mathrm{S} 4$ is $0 \mathrm{~mm}$ and for S2 and S5 is $50 \mathrm{~mm}$ and $100 \mathrm{~mm}$ eccentricity for S3 and S6. The recorded most extreme story force was more than the calculated story strength at beam yielding for every example. This showed all the examples yielded in the beam during testing. For examples of the same arrangement, the relations between story force and story drift were comparable. Every example developed beam yielding before $2 \%$ story drift and maintained the story strength at beam

\section{Volume 6 Issue 12, December 2017}

\section{www.ijsr.net}




\section{International Journal of Science and Research (IJSR) \\ ISSN (Online): 2319-7064}

Index Copernicus Value (2016): 79.57 | Impact Factor (2015): 6.391

yielding until $4 \%$ story drift and, therefore, showed great ductile behavior.

\section{Hung-Jen Lee, and Jen-Wen Ko}

Studied five RC beam column joint were designed, constructed and tested under reversed cyclic loading. The measured displacements responses for example S0 and S50, are fundamentally the same as in stiffness, strength, and ductility. In the first place beam bar yielding was measured during the $1.0 \%$ drift cycle and most extreme load was recorded at $5 \%$ drift level. The load displacement reactions of the $\mathrm{W}$-arrangement examples were comparative up to $4 \%$ drift after yielding of beam bars ( $1 \%$ drift) and joint crossties ( $2 \%$ to $3 \%$ drift cycle). The rate of strength degradation from first to third cycle of 5\% drift level was around $10 \%$ for example W0 and W75, however it was around $30 \%$ for example W0 and W75, however it was around 30\% and W150 at the same drift level. Since the most extreme loads of example S0 and S50 were govern by beam flexure as opposed to joint shear, $\mathrm{S}$-arrangement examples had around $20 \%$ over strength and a ductility ratio more than 5 . Contrast, example W0 and W75 had around 10\% over strength and a ductility ratio of 4.4 due to in-complete arrangement of beam plastic hinges. Finally, example W150 had just 3\% over strength and a less ductile ratio of 3.3. Eccentric between beam and column centerlines had detrimental effects on the strength degradation.

\section{Comparison of Codal Provisions}

\subsection{Introduction}

In this chapter, comparison is made between the provisions of reinforcement for exterior beam column joints with two international codes namely Indian code (IS:13920-1993), American code (ACI 318M-14).

\subsection{American code (ACI 318-14)}

The importance of beam-column joint design and detailing was first highlighted in the SEAOC (1966) (Structural Engineers Association of California). According to ACI 318, until the beginning of the 1970s only. ACI 318-71 include an appendix of special provision for seismic design including provisions for beam-column joint shear design based on the work of Hanson \& Connor (1967).

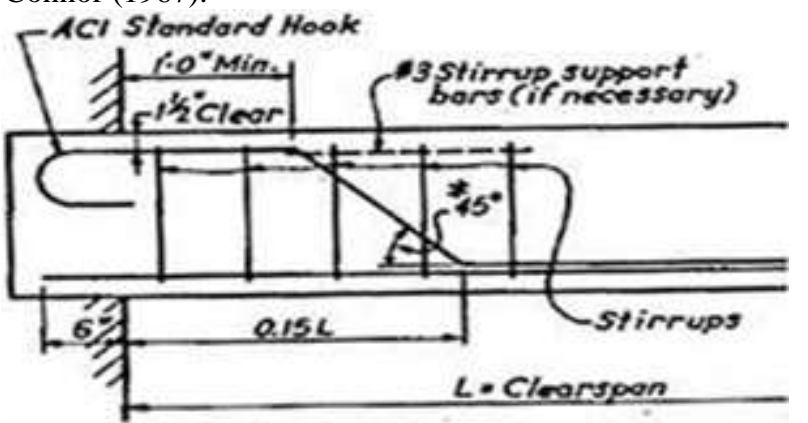

Figure 3.2.1: Design and detailing of beam-column joints in USA

In the recommendations of ACI 318-71 and of SEOC anchorages of longitudinal beam bars in joint region with $90^{\circ}$-hooks bent away and with $180^{\circ}$-hooks were allowed, although the $90^{\circ}$-bent in hooks preferred (Fig. 3.1). ACI
352-76 was the first document that extensively addressed the design of beam column joints. Special focus was given not only to the anchorage length of the beam bars, but also to the transverse reinforcement and the resistance of the confining members. The joint detailing provided by the ACI $318-14$ is valid nowadays.

\subsection{Indian code (IS 13920-1993)}

Provisions concerning the anchorage of smooth and deformed longitudinal deformed bars of reinforced concrete members are provided in the "Handbook of Concrete Reinforcement and Detailing", SP 34:1987 for non-seismic applications The handbook is an explanatory document of IS 456:1978. This handbook directly addresses the detailing of beam-column joints requiring larger anchorage length $(\mathrm{Ld}+$ 10d) and the presence of transverse reinforcement (Fig.3.2). Similar provisions are required by the code for "Ductile Detailing of Reinforced Concrete Structures Subjected to Seismic Forces" (IS 13920:1993). Similar detailing requirements are contained in newer version of the Indian seismic standard (For ex. IS 1893:2002).

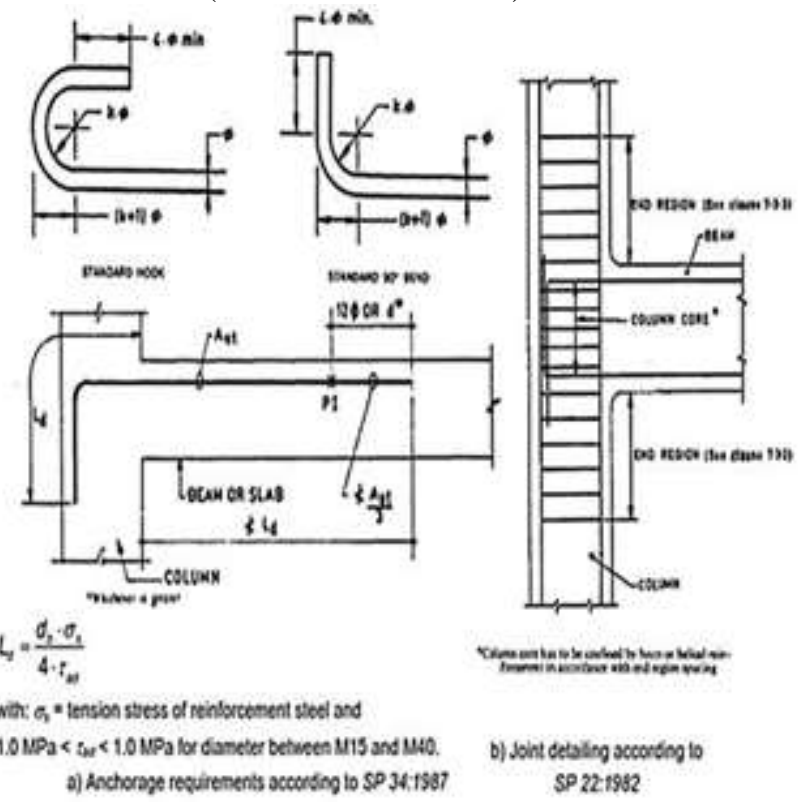

Figure 3.2.2: Reinforcement anchorage according to IS Code

\section{Results and Discussion}

\subsection{Introduction}

In this part the correlation is made for exterior beam column joint with two International codes in particular, IS 139201993, ACI 318-14. The investigation is made for exterior beam column joint in terms of deflection, maximum stress, minimum stress, von misses stress utilizing ANSYS programming bundle for the axial loads and bending moment obtained from the ETABS results.

\subsection{External B-C joint for varying development length} as per different country codes without subjecting to seismic forces

The development length varies as per different International codes. The development length as indicated by Indian code

\section{Volume 6 Issue 12, December 2017}




\section{International Journal of Science and Research (IJSR) \\ ISSN (Online): 2319-7064 \\ Index Copernicus Value (2016): 79.57 | Impact Factor (2015): 6.391}

relies upon the bar diameter and American code relies on upon the diameter of the bar and also grade of concrete considered in the analysis of the building. In the present study, analysis results obtained for exterior beam column joints selected from the building analyzed without considering seismic forces are introduced in Table.

Beam Column joint varying development length according to different codes without considering seismic forces

\begin{tabular}{|c|c|c|}
\hline Beam $300 \times 450 \mathrm{~mm}$ & \multicolumn{2}{|c|}{ Column $300 \times 600 \mathrm{~mm}$} \\
\hline \multicolumn{2}{|c|}{ Axial Force $=200 \mathrm{kN}$ and Bending Moment $=-70 \mathrm{kN}-\mathrm{m}$} \\
\hline \multirow{2}{*}{ Parameters Studied } & Indian Code & American Code \\
\cline { 2 - 3 } & IS 13920-1993 & ACI 318-14 \\
\hline Development Length, mm & 802 & 305 \\
\hline Deflection, $\mathrm{mm}$ & 0.70443 & 0.70992 \\
\hline Min Stress, N/mm 2 & -7.035 & -9.148 \\
\hline Max Stress, N/mm & 0.907 & 1.18 \\
\hline Von Mises Stress, N/mm & 8.447 & 8.447 \\
\hline
\end{tabular}

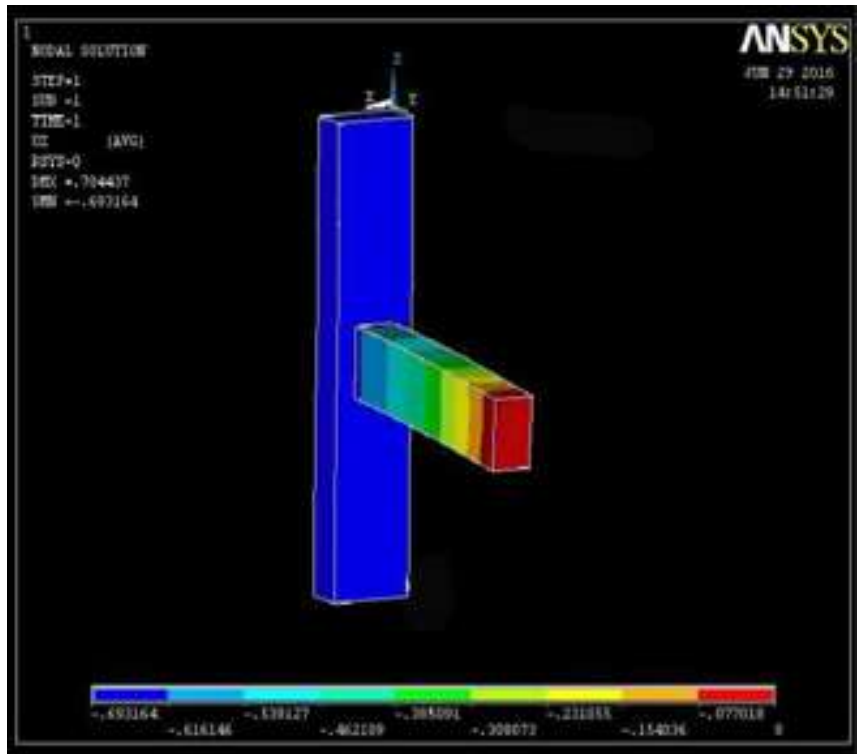

Figure 4.1: Deflection according to IS 13920-1993

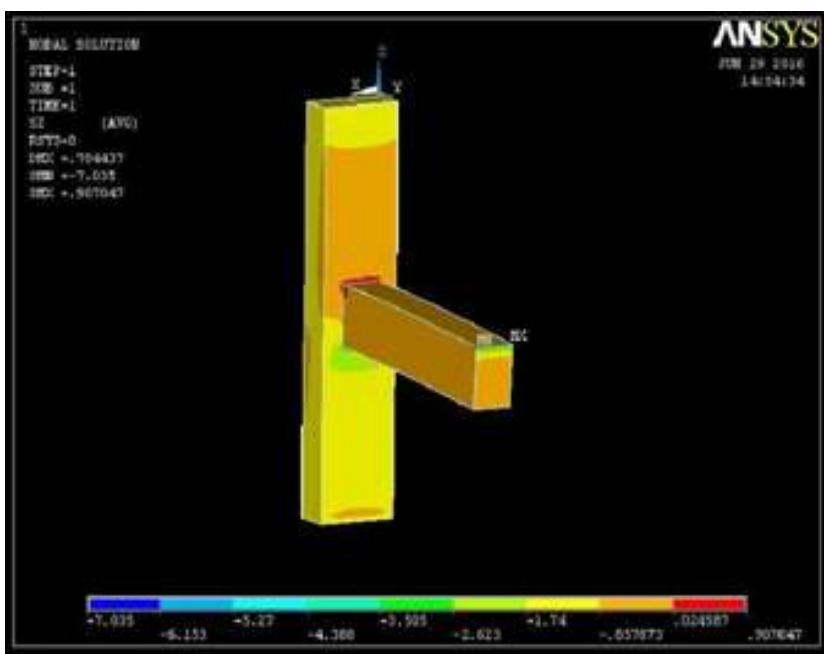

Figure 4.2: Maximum and minimum stress according to (IS 13920-1993)

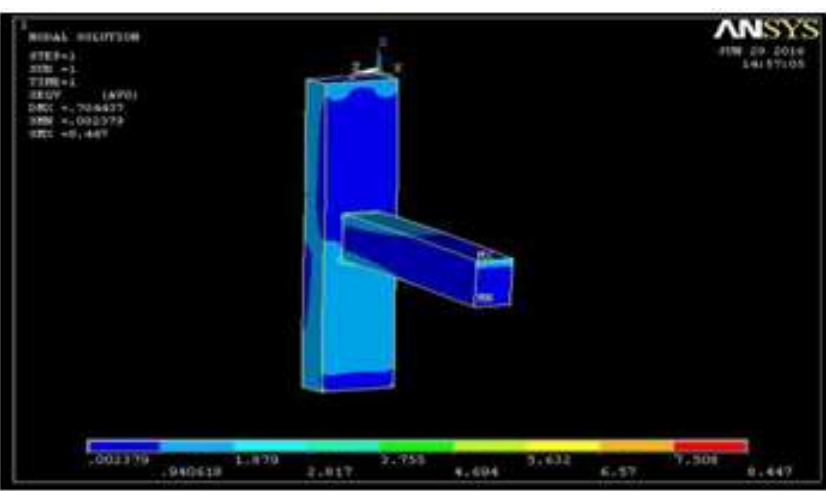

Figure 4.3: Von Mises stress according to IS 13920-1993

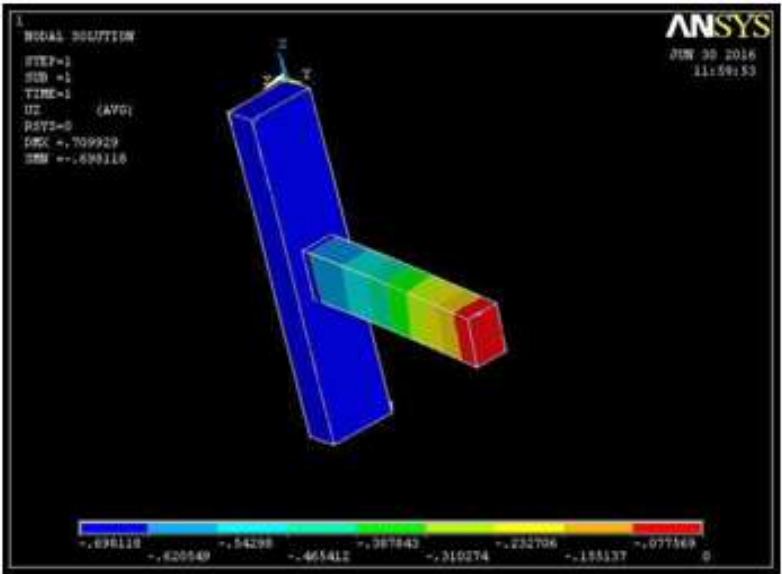

Figure 4.4: Deflection according to ACI 318-14

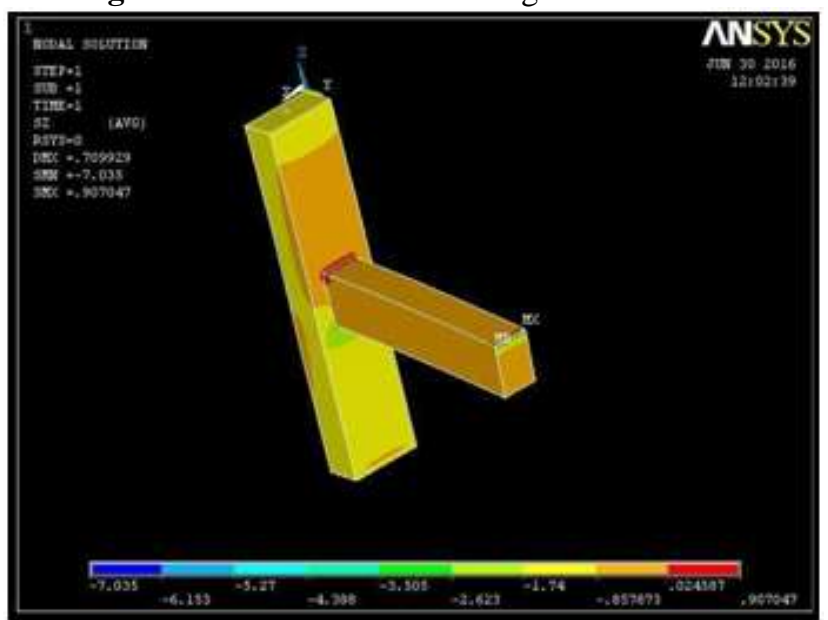

Figure 4.5: Von Mises stress according to ACI 318-14

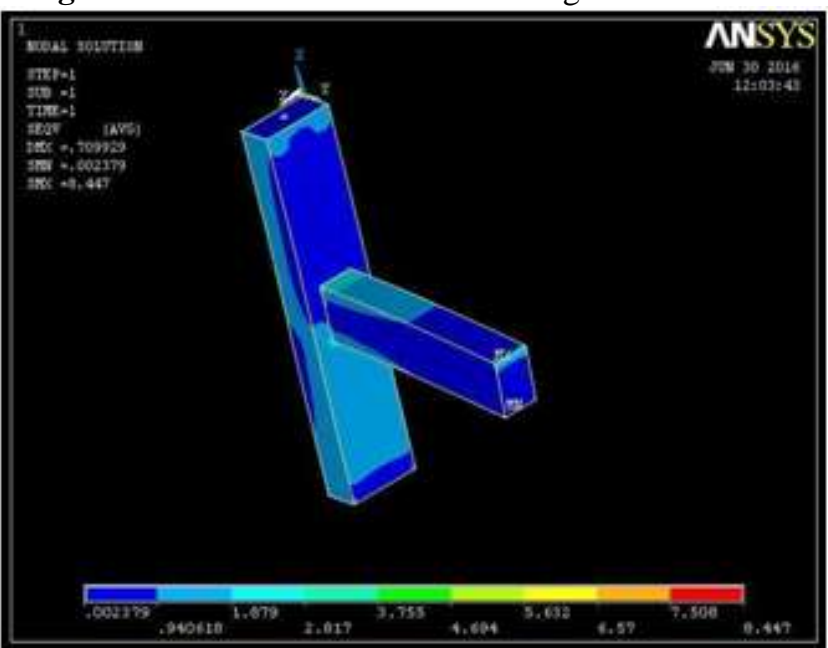

Figure 4.6: Von Mises stress according to ACI 318-14

Volume 6 Issue 12, December 2017

www.ijsr.net

Licensed Under Creative Commons Attribution CC BY 


\section{International Journal of Science and Research (IJSR) \\ ISSN (Online): 2319-7064}

Index Copernicus Value (2016): 79.57 | Impact Factor (2015): 6.391

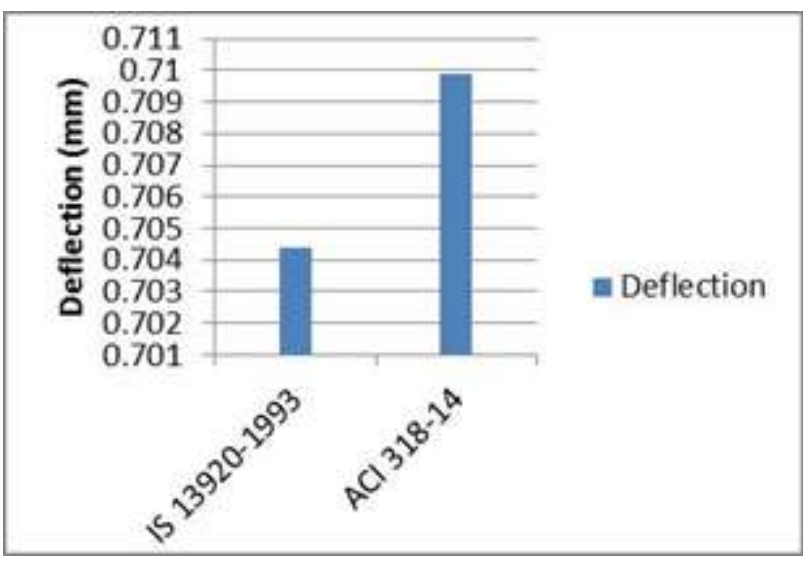

Figure 4.7: Deflection graph according to different code without EQ

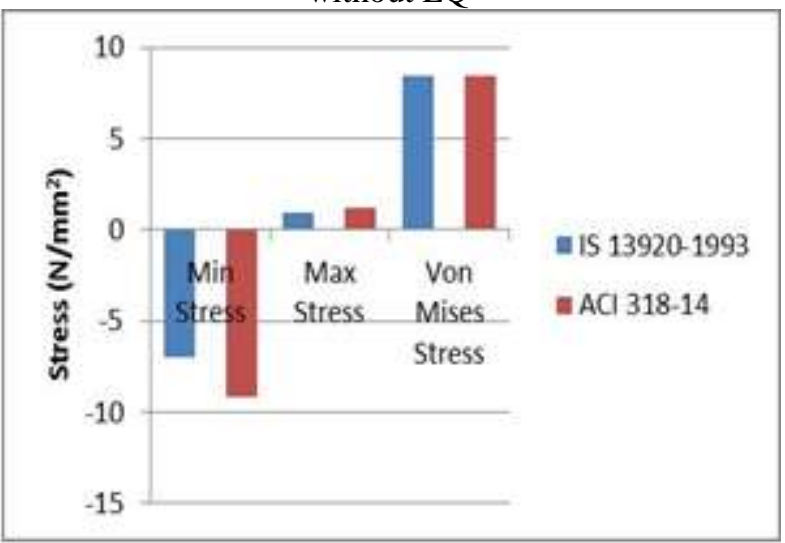

Figure 4.8: Min, max and von mises graph according to different code without EQ

The development length according to the IS 13920-1993 is $802 \mathrm{~mm}$ ACI $318-14$ is $305 \mathrm{~mm}$ are considered for beamcolumn joint. The results obtained are tabulated in Table 5.1 and graphs are plotted in Figure 5.7 and 5.8. The deflection obtained at free end according to IS 13920-1993 and ACI $318-14$ codes is $0.70443 \mathrm{~mm}$ and $0.70992 \mathrm{~mm}$ as shown in fig 5.7. Then the minimum and maximum stress and von mises stress according to IS 13920-1993 and ACI 318-14 are shown in fig 5.8. The axial load on the column and bending moment is provided at the junction is lesser in selected beam-column joint i.e. $200 \mathrm{kN}$ and $70 \mathrm{kN}-\mathrm{m}$. The deflection and stress values in the concentric beam-column joint are lesser than the eccentric beam-column joint. According to IS 13920-1993 and IS 456-2000 the development length is calculated using

$$
1_{\mathrm{d}}=\frac{\oint \sigma_{\mathrm{g}}}{4 \tau_{\mathrm{bd}}}
$$

Beam Column joint of $150 \mathrm{~mm}$ eccentricity and varying development length according to different codes without considering seismic forces

\begin{tabular}{|c|c|c|}
\hline Beam $300 \times 450 \mathrm{~mm}$ & \multicolumn{2}{|c|}{ Column $300 \times 600 \mathrm{~mm}$} \\
\hline \multicolumn{2}{|c|}{ Axial Force $=200 \mathrm{kN}$ and } & Bending Moment $=-70 \mathrm{kN}-\mathrm{m}$ \\
\hline \multirow{2}{*}{ Parameters Studied } & Indian Code & American Code \\
\cline { 2 - 3 } & IS $13920-1993$ & ACI 318-14 \\
\hline Development Length, mm & 802 & 305 \\
\hline Deflection, $\mathrm{mm}$ & 0.049 & 0.0498 \\
\hline Min Stress, N/mm & -7.861 & -7.89 \\
\hline Max Stress, N/mm & 1.236 & 1.303 \\
\hline Von Mises Stress, N/mm ${ }^{2}$ & 8.486 & 8.526 \\
\hline
\end{tabular}

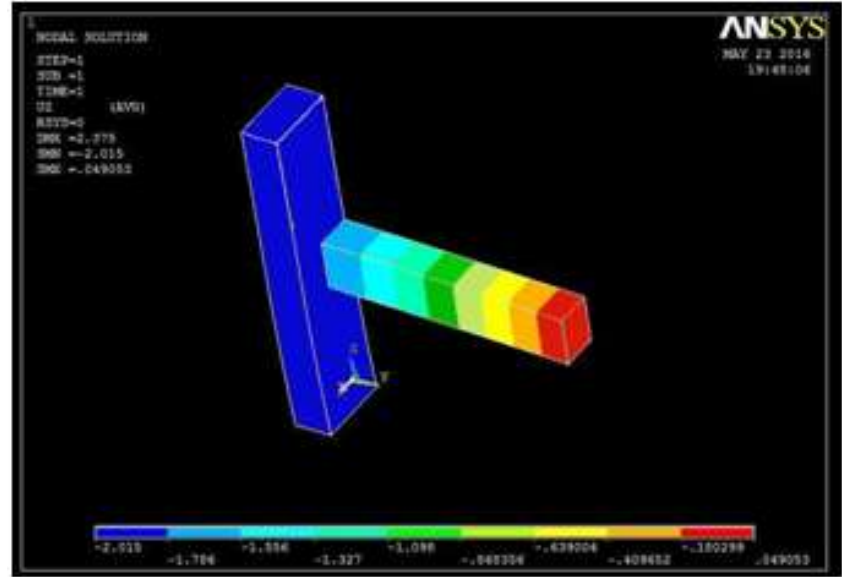

Figure 4.9: Deflection according to IS 13920-1993

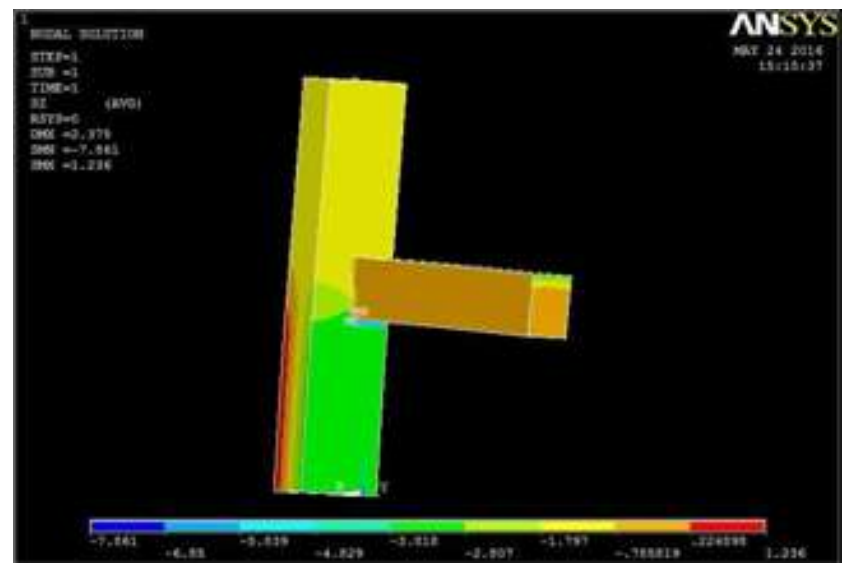

Figure 4.10: Maximum and minimum stress According to IS $13920-1993$

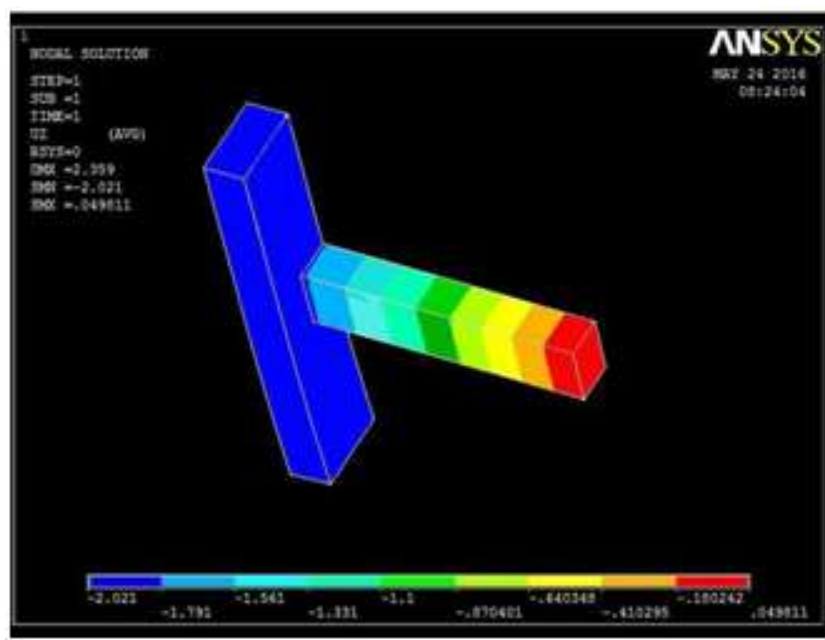

Figure 4.11: Deflection according to ACI 318-14

Volume 6 Issue 12, December 2017 www.ijsr.net 


\title{
International Journal of Science and Research (IJSR) \\ ISSN (Online): 2319-7064
}

Index Copernicus Value (2016): 79.57 | Impact Factor (2015): 6.391

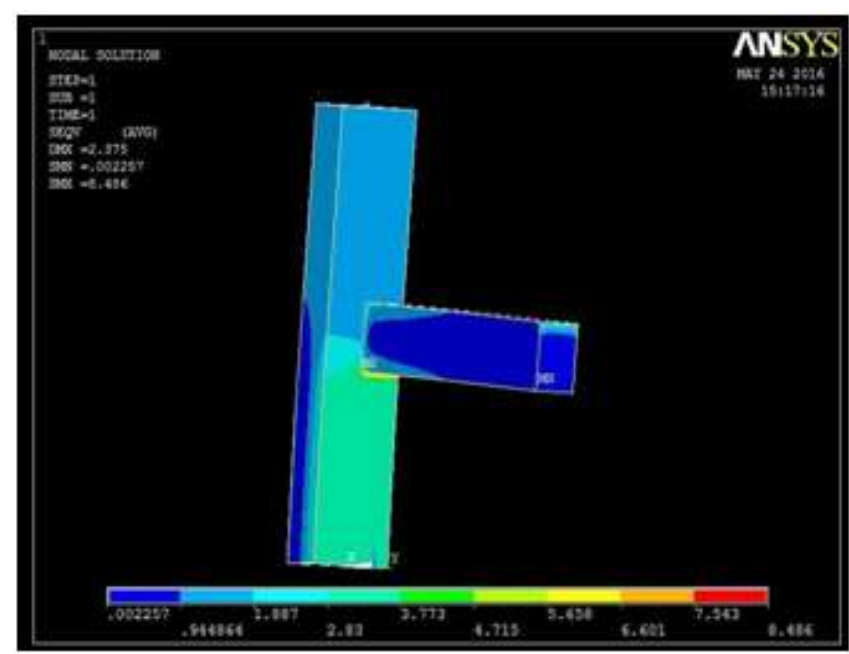

Figure 4.12: Von Mises stress according to IS 13920-1993

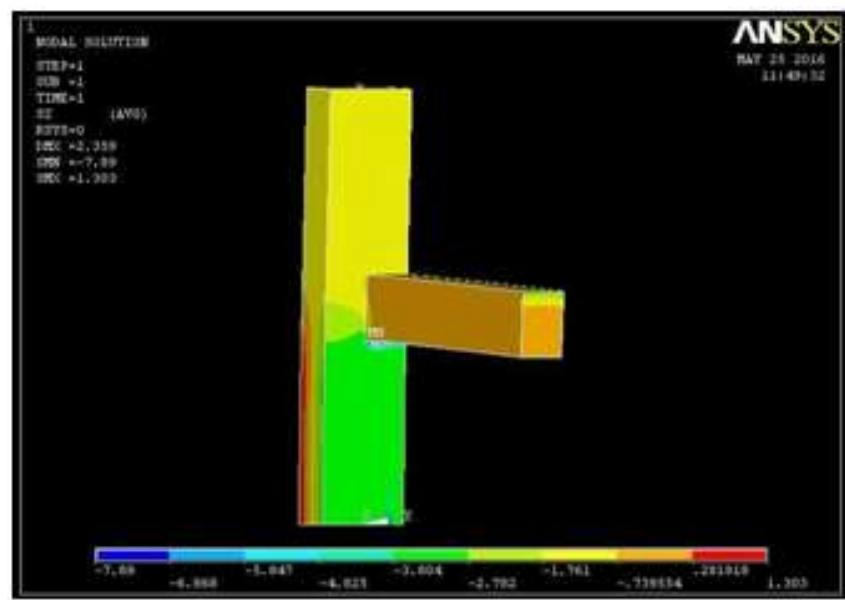

Figure 4.13: Maximum and minimum stress According to ACI 318-14

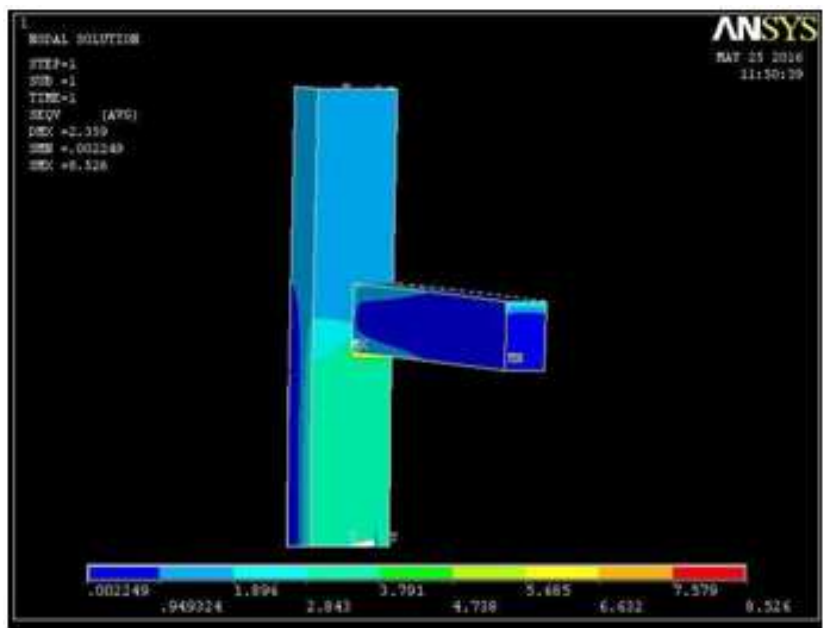

Figure 4.14: Von Misses stress according to ACI 318-14

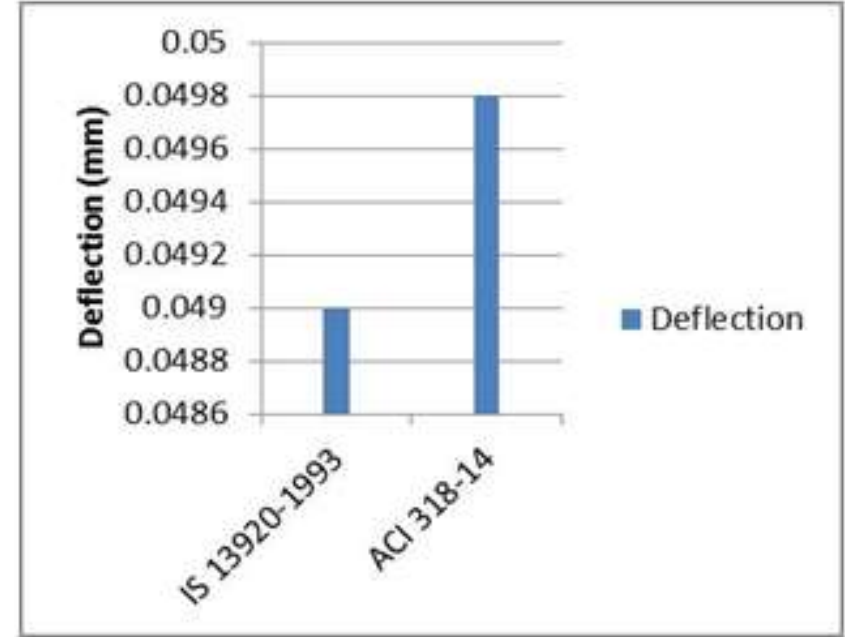

Figure 4.14: Deflection graph according to different code without EQ

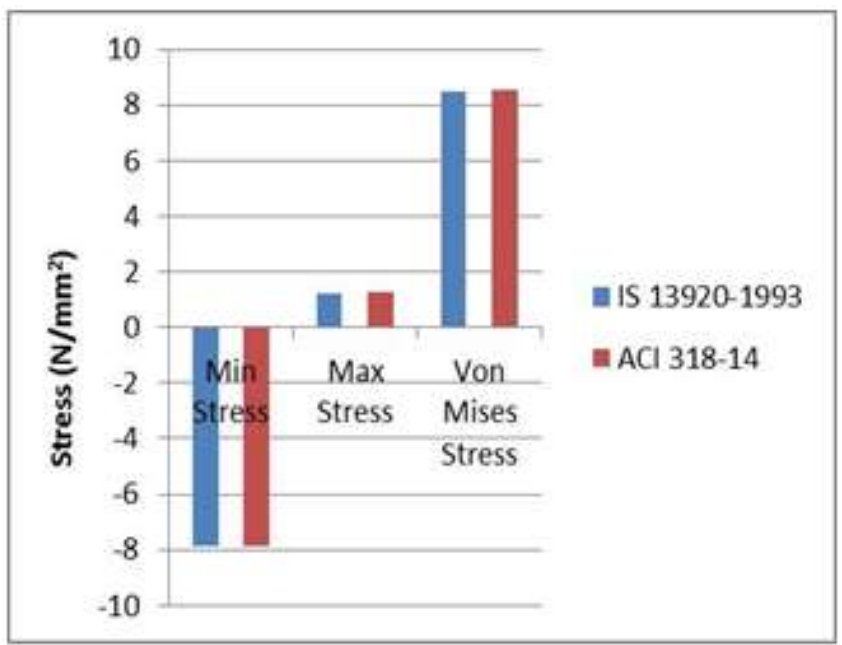

Figure 5.32: Min, max and von mises graph according to different code without EQ

The development length according to the IS 13920-1993 is $802 \mathrm{~mm}$ ACI $318-14$ is $305 \mathrm{~mm}$ are considered for beamcolumn joint. The eccentricity of $150 \mathrm{~mm}$ is provided to the beam in the model. The deflection obtained at free end according to IS $13920-1993$ and ACI $318-14$ codes is 0.0490 $\mathrm{mm}$ and $0.0498 \mathrm{~mm}$ as shown in fig 5.25 and 5.28. Then the minimum and maximum stress and von mises stress according to IS 13920-1993 and ACI 318-14 is different in both the cases as shown in fig 5.32. The axial load on the column and bending moment is provided at the junction is lesser in selected beam-column joint i.e, $200 \mathrm{kN}$ and $70 \mathrm{kN}$ $\mathrm{m}$. The stress values increases with the increase in eccentricity.

\subsection{External B-C joint for varying development length as per different country codes with subjecting to seismic forces}

The development length gave by various International codes. In this study, nonlinear arrangements are acquired for exterior beam column joints chose from the building dissected considering seismic are displayed in Table 5.5. The deflection occurred at the free end as per IS 139201993, ACI 318-14 codes with considering seismic forces.

\section{Volume 6 Issue 12, December 2017}

\author{
www.ijsr.net
}




\section{International Journal of Science and Research (IJSR) \\ ISSN (Online): 2319-7064 \\ Index Copernicus Value (2016): 79.57 | Impact Factor (2015): 6.391}

Table 4.5: Beam Column joint of varying development length according to different codes with considering

\begin{tabular}{|c|c|c|}
\hline \multicolumn{3}{|c|}{ seismic forces } \\
\hline Beam $300 \times 450 \mathrm{~mm}$ & \multicolumn{2}{|c|}{ Column $300 \times 600 \mathrm{~mm}$} \\
\hline Axial Force $=250 \mathrm{kN}$ and Bending Moment = $-115 \mathrm{kN}-\mathrm{m}$ \\
\hline \multirow{2}{*}{ Parameters Studied } & Indian Code & American Code \\
\cline { 2 - 3 } & IS 13920-1993 & ACI 318-14 \\
\hline Development Length, mm & 850 & 400 \\
\hline Deflection, mm & 0.91338 & 0.92038 \\
\hline Min Stress, N/mm ${ }^{2}$ & -9.148 & -9.148 \\
\hline Max Stress, N/mm ${ }^{2}$ & 1.18 & 1.18 \\
\hline Von Mises Stress, N/mm & 10.984 & 10.984 \\
\hline
\end{tabular}

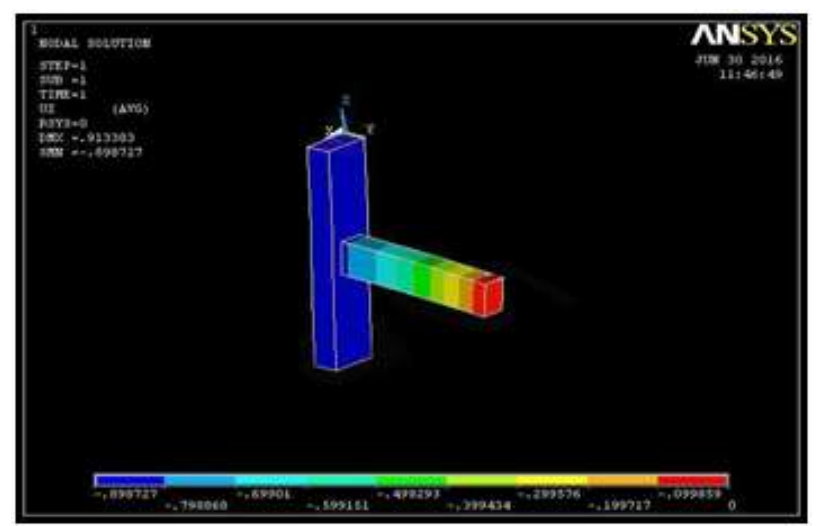

Figure 4.15: Deflection according to IS 13920-1993

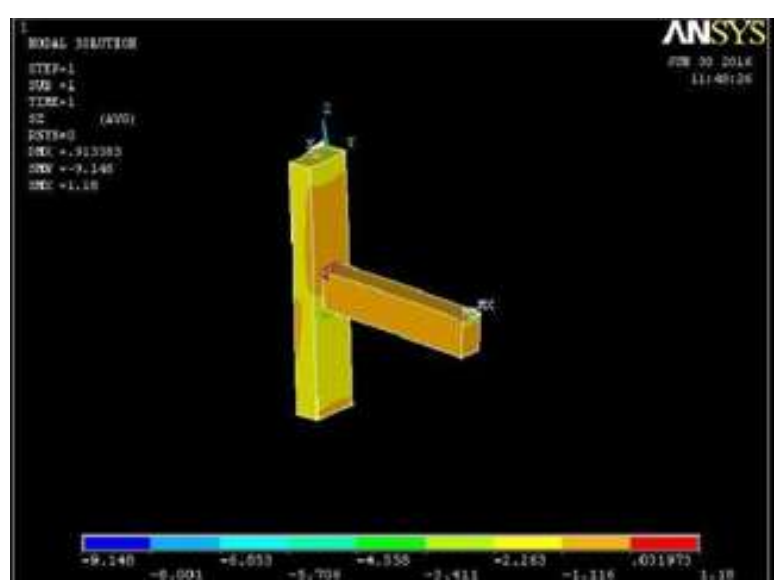

Figure 4.16: Maximum and minimum stress according to IS 13920-1993

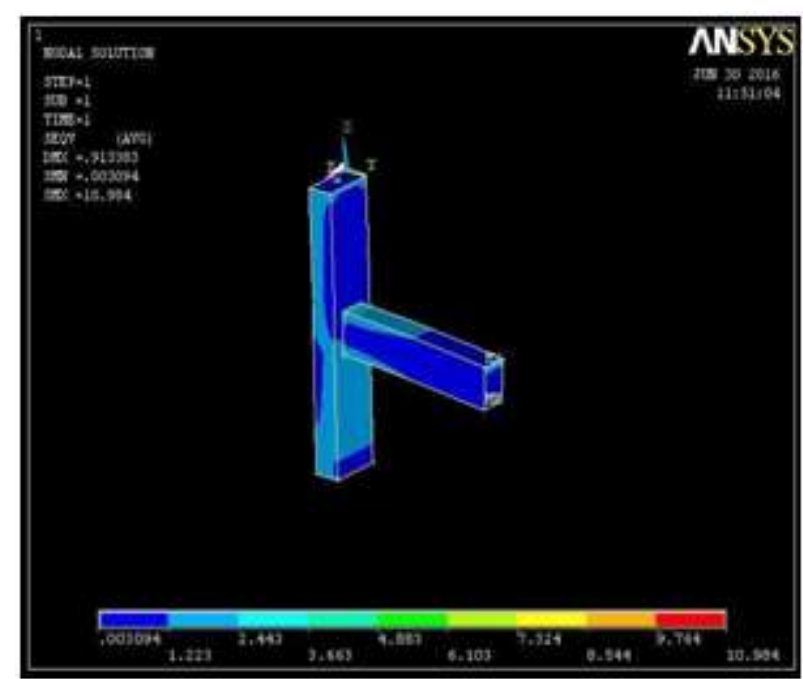

Figure 4.17: Von Mises stress according to IS 3920-1993

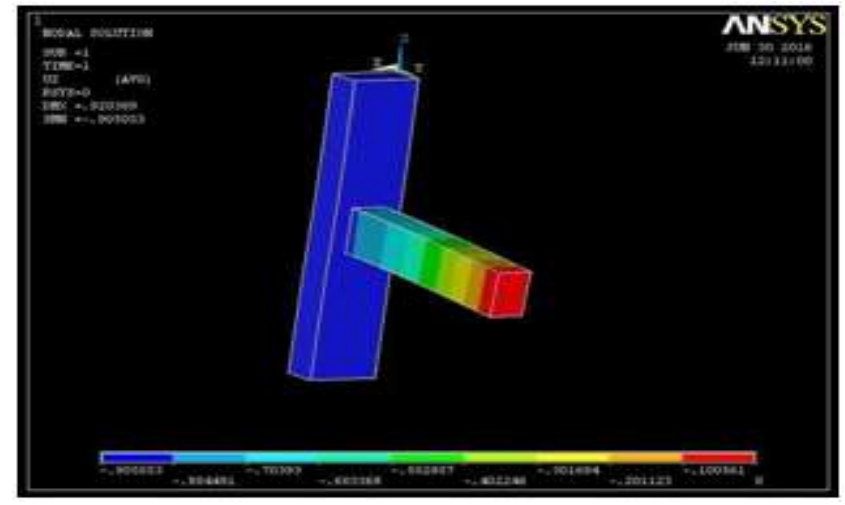

Figure 4.18: Deflection according to ACI 318-14

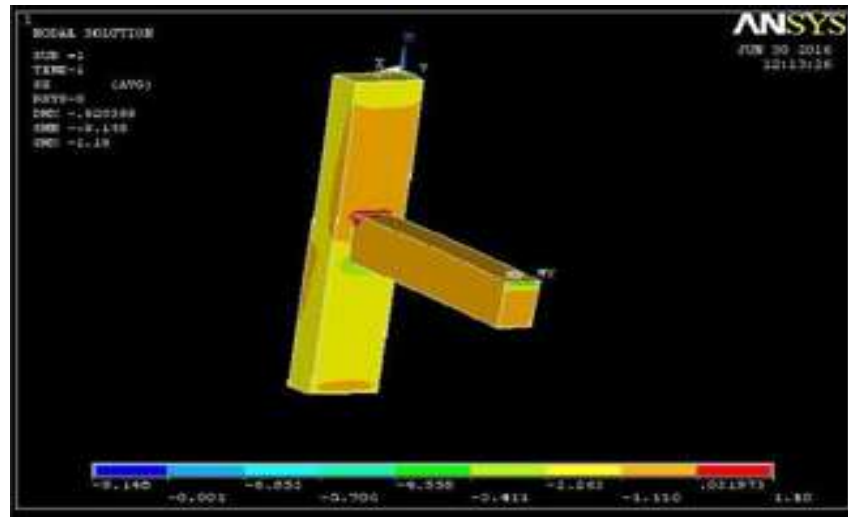

Figure 4.19: Maximum and minimum stress According to ACI 318-14

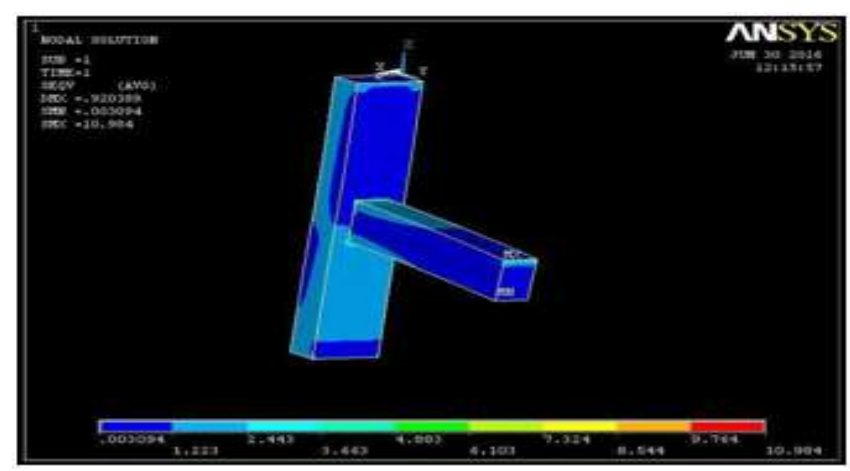

Figure 4.20: Von Mises stress according to ACI 318-14

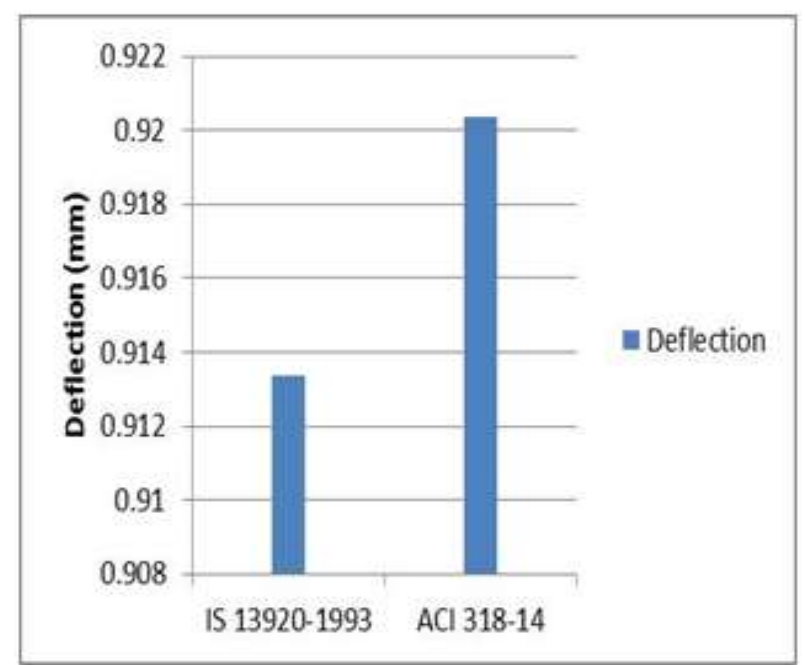

Figure 4.21: Deflection graph according to different code with EQ

\section{Volume 6 Issue 12, December 2017} www.ijsr.net 


\section{International Journal of Science and Research (IJSR) \\ ISSN (Online): 2319-7064}

Index Copernicus Value (2016): 79.57 | Impact Factor (2015): 6.391

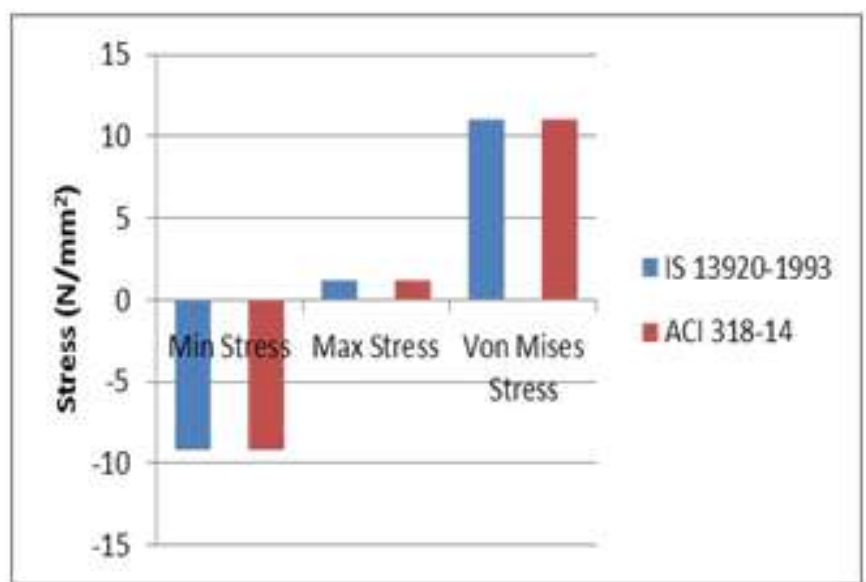

Figure 4.22: Min, max and von mises graph according to different code with EQ

The development length according to the IS 13920-1993 is $850 \mathrm{~mm}$ ACI $318-14$ is $400 \mathrm{~mm}$ are considered for beamcolumn joint. The deflection obtained at free end according to IS $13920-1993$ and ACI $318-14$ codes is $0.91338 \mathrm{~mm}$ and $0.92038 \mathrm{~mm}$ as shown in fig 5.33 and 5.36. Then the minimum stress is same in both the cases and maximum stress is different in both the cases and von mises stress according to Is $13920-1993$ and ACI $318-14$ is same as shown in fig 5.40 .

The axial load on the column and bending moment is provided at the junction is lesser in selected beam-column joint i.e, $250 \mathrm{kN}$ and $115 \mathrm{kN}-\mathrm{m}$. There is difference in the deflection values is due to concentric beam-column joint.

Beam Column joint of $150 \mathrm{~mm}$ eccentricity and varying development length according to different codes with considering seismic forces

\begin{tabular}{|c|c|c|}
\hline Beam $300 \times 450 \mathrm{~mm}$ & \multicolumn{2}{|c|}{ Column $300 \times 600 \mathrm{~mm}$} \\
\hline Axial Force $=250 \mathrm{kN}$ and Bending Moment $=-115 \mathrm{kN}-\mathrm{m}$ \\
\hline Parameters Studied & Indian Code & American Code \\
\hline & IS 13920-1993 & ACI 318-14 \\
\hline Development Length, mm & 850 & 400 \\
\hline Deflection, $\mathrm{mm}$ & 0.0663 & 0.06734 \\
\hline Min Stress, N/mm & -10.117 & -10.156 \\
\hline Max Stress, N/mm & 1.655 & 1.748 \\
\hline Von Mises Stress, N/mm & 10.979 & 11.033 \\
\hline
\end{tabular}

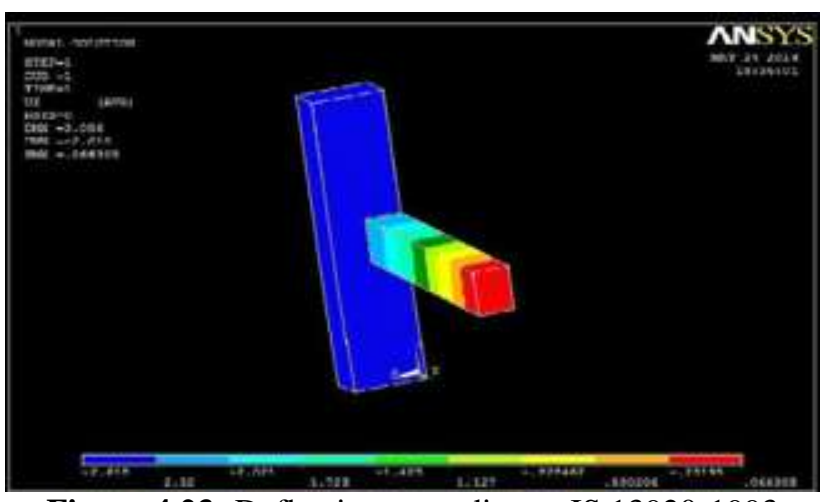

Figure 4.23: Deflection according to IS 13920-1993

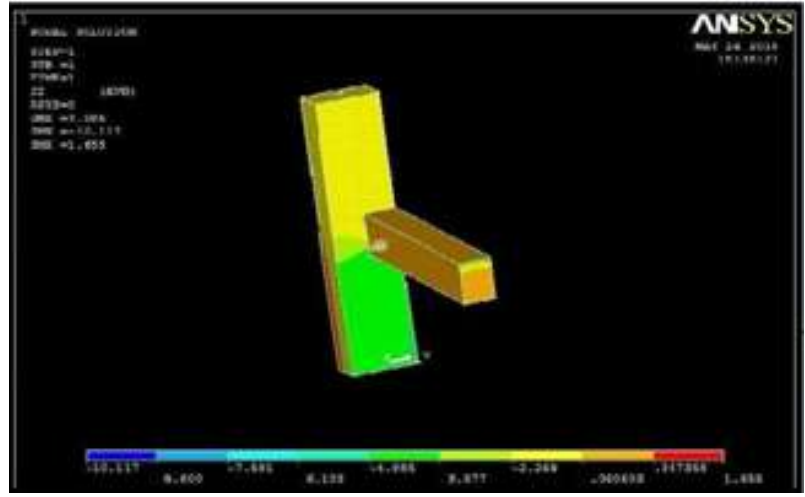

Figure 4.24: Maximum and minimum stress according to IS 13920-1993

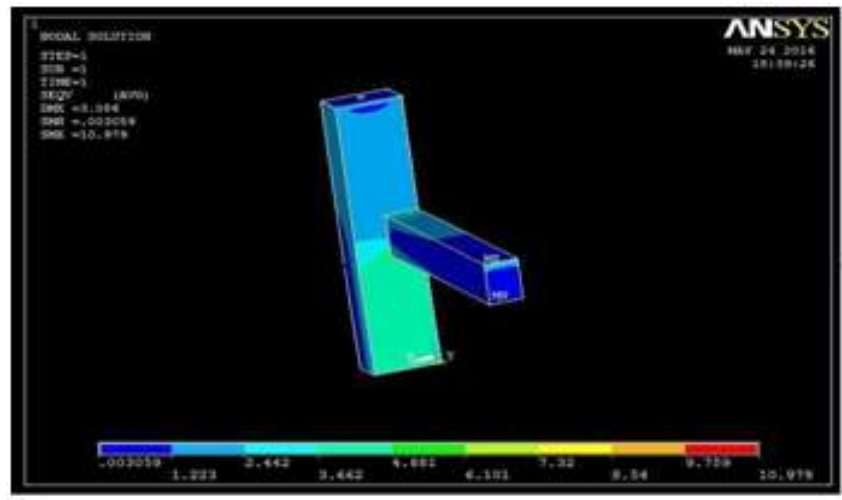

Figure 4.25: Von Mises stress according to IS 13920-1993

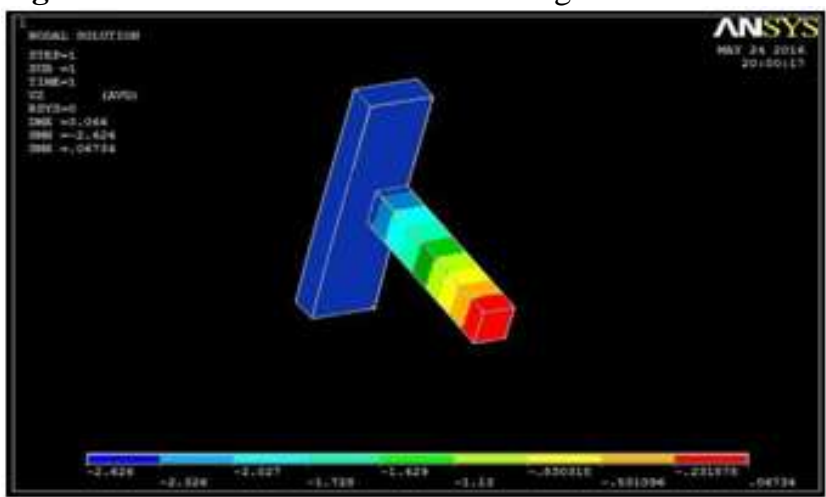

Figure 4.26: Deflection according to ACI 318-14

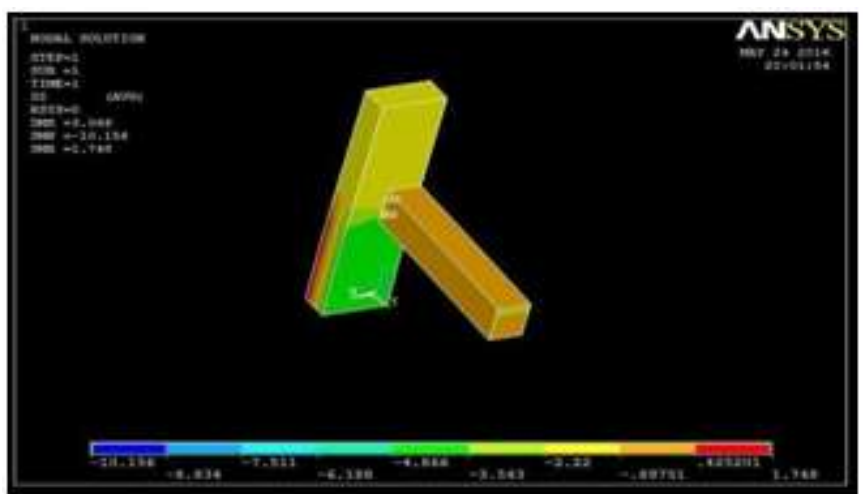

Figure 4.27: Maximum and minimum stress according to ACI 318-14

Volume 6 Issue 12, December 2017 www.ijsr.net 


\section{International Journal of Science and Research (IJSR) \\ ISSN (Online): 2319-7064 \\ Index Copernicus Value (2016): 79.57 | Impact Factor (2015): 6.391}

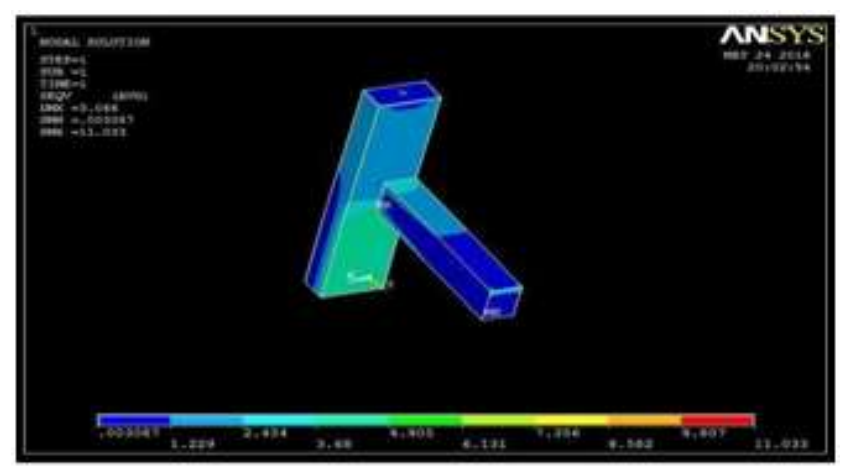

Figure 4.28: Von Mises stress according to ACI 318-14

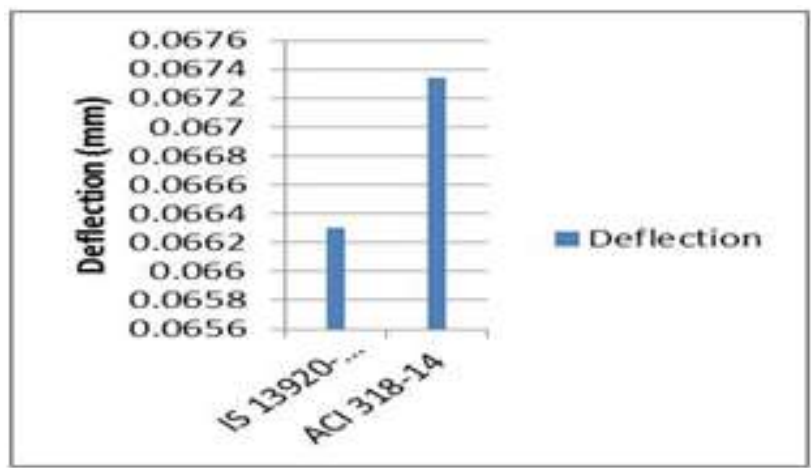

Figure 4.29: Deflection graph according to different code with EQ

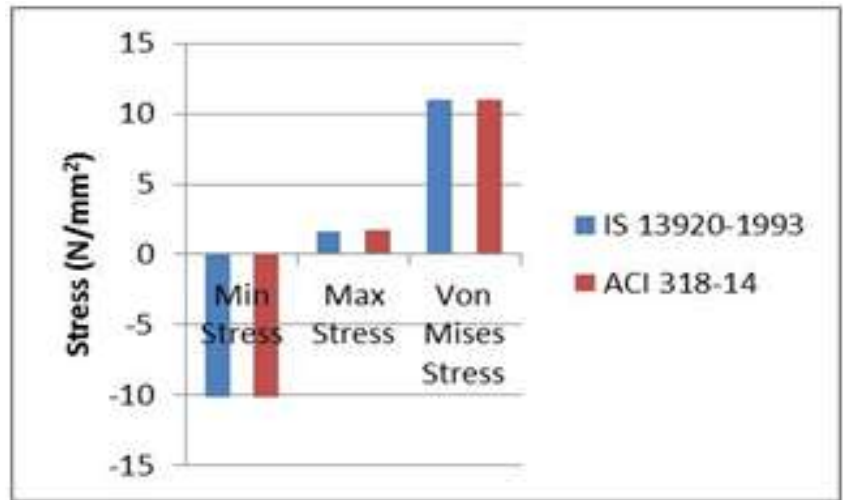

Figure 4.30: Min, max and von misses graph according to different code with EQ

The development length according to the IS 13920-1993 is $850 \mathrm{~mm}$ ACI $318-14$ is $400 \mathrm{~mm}$ are considered for beam-column joint. The eccentricity of $150 \mathrm{~mm}$ is provided to the beam with the column centroid in the model. The deflection obtained at free end according to IS $13920-1993$ and ACI $318-14$ codes is $0.0663 \mathrm{~mm}$ and $0.0673 \mathrm{~mm}$ as shown in fig 5.57 and 5.60. Then the minimum and maximum stress and von mises stress according to Is 13920-1993 and ACI 318-14 is different as shown in fig 5.64. The axial load on the column and bending moment is provided at the junction is lesser in selected beam-column joint i.e., $250 \mathrm{kN}$ and $115 \mathrm{kN}-\mathrm{m}$.

\section{Conclusion}

The Axial load on the Column and Bending Moment is Provided at the Junction is lesser in selected Beam-Column Joint i.e, $200 \mathrm{KN}$ and $70 \mathrm{KN}-\mathrm{m}$. The Deflection and stress values in the Concentric Beam Column Joint are lesser than the Eccentric Beam Column Joint.

Development Length according to IS code is $802 \mathrm{~mm}$ and ACI is $305 \mathrm{~mm}$ are considered for Beam Column Joint. The Eccentricity of $150 \mathrm{~mm}$ is provided to the beam in the model.

Minimum and Maximum stress and von mises stress according to IS 13920-1993 and ACI 318-14 is different in both the cases. The stress values increases with the increase in eccentricity.

The development length according to the IS 13920-1993 is $850 \mathrm{~mm}$ ACI $318-14$ is $400 \mathrm{~mm}$ are considered for beamcolumn joint by considering EQ. The deflection obtained at free end according to IS 13920-1993 and ACI 318-14 codes is same.

Then the minimum stress is same in both the cases and maximum stress is different in both the cases and von misses stress according to Is 13920-1993 and ACI 318-14 is same. The axial load on the column and bending moment is provided at the junction is lesser in selected beam-column joint i.e., $250 \mathrm{kN}$ and $115 \mathrm{kN}-\mathrm{m}$. There is difference in the deflection values is due to concentric beam-column joint.

The eccentricity of $150 \mathrm{~mm}$ is provided to the beam with the column centroid in the model. Then the minimum and maximum stress and von mises stress according to IS and ACI

is different.

\section{References}

[1] Joh, O. Goto, Y. and Shibata, T., "Behavior of Reinforced Concrete Beam-Column Joints with Eccentricity," Design of

[2] Beam-Column Joints for Seismic Resistance, SP-123, J. O. Jirsa, ed., American Concrete Institute, Farmington Hills, MI, pp. 317-357, 1991.

[3] Gregory S. Raffaelle and James K. Wight, "Reinforced concrete eccentric beam column connections subjected to earthquake type loading" ACI structural journal, title no. $92-86,1995$.

[4] Cheng-Cheng Chen and Gwang-Kai Chen, "Cyclic behavior of reinforced concrete eccentric beam-column corner joint connecting spread ended beam" ACI structural journal, title no. 96-S50, 1999.

[5] Shyh-Jiann Hwang and Hung-Jen Lee, "Analytical model for predicting shear strength of exterior reinforced concrete beam column joints for seismic resistance" ACI structural journal, title no. 96-S93, 1999.

[6] Vollum, R. L., and Newman, J. B., "Towards the Design of

[7] Reinforced Concrete Eccentric Beam-Column Joints," Magazine of Concrete Research, V.51, No. 6, Dec, pp. 397-407, 1999.

[8] Susanto Teng and Hua Zhou, "Eccentric reinforced beam column joints subjected to cyclic loading" ACI structural journal, title no.100S-15, 2003.

[9] Myoungsu Shin and James M. LaFave, "Seismic performance of reinforced concrete eccentric beam column connections with floor slabs" ACI structural

\section{Volume 6 Issue 12, December 2017}




\section{International Journal of Science and Research (IJSR) \\ ISSN (Online): 2319-7064}

Index Copernicus Value (2016): 79.57 | Impact Factor (2015): 6.391

journal, title no.101-S41, 2004.

[10] Hung-Jen Lee, and Jen-Wen Ko, "Eccentric reinforced concrete beam column connections subjected to cyclic loading in principal directions" ACI structural journal, title no.104S-44,2007.

[11] Takashi Kashiwazaki and Hiroshi Noguchi, "Seismic performance evaluation of reinforced concrete eccentric beam column joints using three dimensional FEM analysis" 13th world conference on earthquake engineering Vancouver, B.C., Canada Paper No.1354, 2007.

[12] Tomohiko Kamimura, Hiroyasu Takimoto, and Shinya

[13] Tanaka, "Mechanical behavior of reinforced concrete beam column assemblages with eccentricity" 13th world conference on earthquake engineering Vancouver, B.C., Canada Paper No.4, 2007.

[14] Yasuaki Goto, Osamu Joh, "Shear resistance of reinforced concrete interior eccentric beam column joints" 13th world conference on earthquake engineering Vancouver, B.C., Canada Paper No.649, 2007.

Volume 6 Issue 12, December 2017

www.ijsr.net 